\title{
DISCUSSION
}

\section{The vadose zone water balance and transpiration rates of vegetation}

\author{
G. E. BLIGHT (2003). Géotechnique 53, No. 1, 55-64
}

\section{A. D. M. Penman, Geotechnical Engineering Consultant} Professor Blight has described the drying effect of poplar trees in South Africa.

Here in the UK our government offered compensation for bomb damage, and it was found that claims were coming from areas where there were no recorded bomb strikes. To check on this our Building Research Station was asked to investigate, and during the 1943-1945 period we found very many houses with shallow foundations on heavy clay soil that had suffered considerable damage. The worst cases were where poplar trees had been planted, often in rows as screens between adjacent houses. We made a recommendation that a poplar tree should not be closer to a house than its mature height, and that rows should be distanced $1 \frac{1}{2}$ times their height. Shrinkage of the soil caused by extraction of water by the trees during the summer left the brickwork of the house in tension. During the winter the soil could swell and relieve the tension, but the ground shock from a bomb, which might be some distance off, could be sufficient to cause tensile failure, resulting in wide cracks. Our recommendation for new houses on clay soils was to found them on short bored piles, and during the postwar housing boom large numbers of houses on heavy clay soils were founded successfully in this way.

\section{Author's reply}

The author thanks Dr Penman for a most interesting discussion on the effects of soil drying on house foundations subjected to bomb blasts.

The author has also been interested in the drying effects of vegetation for many years (e.g. Blight, 1997). The trigger for his most recent research was the banning of poplar and other exotic tree species in South Africa as 'undesirable alien vegetation' on the grounds that they transpire excessive amounts of water and deplete the country's water resources. However, when the water consumption of deciduous poplars is compared with that of evergreen indigenous trees and bushes, it is found that the alien poplars use less water per square metre of soil surface than do evergreen indigenous species. The banning of these beautiful trees is an example of a political decision made on the basis of sentiment and folklore rather than scientific fact.

\section{REFERENCE}

Blight, G. E. (1997). Interactions between the atmosphere. Rankine Memorial Lecture. Géotechnique 47, No. 4, 715-766 